\title{
Potensi Manajerial Kelas Yang Diperlukan Guru Dalam Peningkatan Mutu Pembelajaran Di Madrasah Aliyah
}

\author{
Iswati ${ }^{1 *}$, Marlina $^{2^{* *}}$ \\ 1 Universitas Muhammadiyah Metro \\ ${ }^{2}$ STKIP NUrul Huda OKU Timur \\ *iswatiummetro@yahoo.com \\ **marlina@stkipnurulhuda.ac.id
}

\begin{abstract}
Abstrak
Tujuan dari penelitian ini untuk mengetahui kompetensi manajerial kelas yang perlu dimiliki oleh guru-guru khususnya di MA di Kota Metro dengan harapan hasil penelitian dapat digunakan sebagai sumbangan pemikiran dan pengetahuan dalam rangka meningkatkan mutu pembelajaran bagi guru secara umum. Berdasarkan hasil temuan penelitian dapat disimpulkan bahwa: potensi manajerial yang diperlukan guru dalam proses pembelajaran dapat dikelompokkan menjadi dua kegiatan pokok, yaitu pengelolaan pengajaran dan pengelolaan kelas. Pengelolaan pengajaran adalah kegiatan mengajar itu sendiri yang melibatkan secara langsung komponen materi pengajaran, metode mengajar dan alat bantu dalam rangka mencapai tujuan pengajaran. Pengelolaan kelas adalah penciptaan kondisi yang memungkinkan pengelolaan pengajaran dapat berjalan secara optimal.
\end{abstract}

Kata kunci: Manajerial Kelas, Kompetensi Guru dan Pembelajaran.

\section{PENDAHULUAN}

Di Indonesia pendidikan menjadi sektor yang mendapat prioritas dari pemerintah sebagai upaya untuk meningkatkan kualitas manusia Indonesia seutuhnya. Untuk itu menjadi hak setiap anak bangsa untuk mendapatkan pendidikan, baik pendidikan secara formal maupun non formal.

Sekolah sebagai salah satu lembaga pendidikan formal memiliki peranan yang sangat penting dalam mewujudkan fungsi dan tujuan pendidikan nasional melalui proses belajar mengajar. Hal tersebut sejalan dengan tujuan pendidikan yang tercantum dalam Undang-Undang Sistim Pendidikan Nasional No. 20 Tahun 2003 pasal 3 bahwa "Pendidikan Nasional bertujuan untuk berkembangnya potensi peserta didik yang beriman dan bertakwa kepada Tuhan Yang Maha Esa, berakhlak mulia, sehat, berilmu, cakap, kreatif, mandiri, menjadi warga Negara yang demokratis dan bertanggung jawab". (Depag,2008:h. 5).

Proses Belajar Mengajar merupakan inti dari proses pendidikan formal dengan guru sebagai pemeran utama. Guru sangat menentukan suasana belajar mengajar di dalam kelas. Guru yang kompeten akan lebih mampu dalam menciptakan lingkungan belajar yang efektif dan efesien di dalam kelas, sehingga hasil belajar siswa berada pada tingkat yang optimal. Keberhasilan tersebut, dipengaruhi banyak faktor terutama terletak pada pengajar (guru) dan yang diajar (siswa), yang berkedudukan sebagai pelaku dan subyek dalam proses tersebut.

Dalam kaitannya dengan kompetensi guru maka pemerintah telah menerbitkan Peraturan Pemerintah Republik Indonesia nomor 19 tahun 2005 tentang Standar Nasional Pendidikan. Kinerja guru pada dasarnya merupakan kinerja atau unjuk kerja yang dilakukan oleh guru dalam melakukan tugasnya sebagai pendidik. (Engkay Kerwati, 2010, h. 77). Rahman dkk menyatakan 
bahwa "Kinerja guru dapat dinilai dari aspek kemampuan Dasar yang harus dimiliki oleh seorang guru yang dikenal dengan "kompetensi guru". (Rahman dkk, 2005,h. 72).

Berkenaan dengan kompetensi yang perlu dimiliki guru profesional Undang-Undang Guru dan Dosen No. 14/2005 pasal 8 menyatakan bahwa ada empat kompetensi yang harus dimiliki guru yaitu kompetensi pedagogik, kompetensi kepribadian (personal), kompetensi professional, kompetensi sosial.

Pentingnya penguasaan guru atas ke empat kompetensi diatas kemudian diwujudkan melalui program sertifikasi guru yang dicanangkan oleh pemerintah sebagai bagian dari peningkatan kualitas guru. Sebagai penuntun bagi pelaksanaan program sertifikasi guru maka pemerintah dalam hal ini Kementerian Pendidikan Nasional mengeluarkan panduan penyusunan perangkat portofolio guru. Di dalamnya ada dua komponen penting yang berkaitan dengan kegiatan pembelajaran di kelas yaitu perencanaan dan pelaksanaan pembelajaran di kelas.

Berdasarkan gambaran dari perencanaan dan pelaksanaan pembelajaran di kelas diatas maka dapat disimpulkan bahwa keduanya mengutamakan kompetensi guru dalam mengelola pembelajaran di kelasnya. Ahli-ahli pendidikan di dunia barat lebih sering menggunakan istilah manajemen kelas daripada istilah mengelola kelas sebagaimana yang diungkapkan oleh

Lefrancois bahwa manajemen kelas sebagai istilah umum yang mengarah kepada semua tindakan guru untuk mengorganisasi kelasnya dan instruksi-instruksi yang digunakan serta pemanfaatan waktu secara efektif dan menyenangkan sehingga memaksimalkan pembelajaran. (Lefrancois, G.R, 2000.h. 78) Manajemen kelas yang efektif juga diyakini dapat mendorong keaktifan siswa yang pada akhirnya mendukung terciptanya pembelajaran yang optimal. (Miller, G., \& Hall, T. P, , 2005, h. 383)

Dalam pembelajaran guru merupakan manager dalam lingkungan belajar, kondusif dan stabilitas proses pembelajaran dipengaruhi oleh kemampuan guru dalam mengelola kelas. Sebagai manager pendidikan, guru kemudian dituntut untuk mampu menciptakan ide-ide kreatif dalam mengajar dan mengelola kelas sehingga dapat membangkitkan motivasi siswa dalam mengikuti pembelajaran dengan baik.

Madrasah Aliyah (MA) yang ada di kota Metro berdasarkan sumber data total jumlahnya ada tujuh, terdiri dari enam MA Swasta di antaranya : MA Muhammadiyah, MA Khusnul Khotimah, MA Ma'arif Roudhotut Tholibin, MA Al - Muhsin, MA Darul A'mal dan MA Tuma'ninah Yasin, dan satu MA Negeri yaitu MAN 1 Metro. (Kantor Kementrian Agama Kota Metro tahun 2018.) Madrasah Aliyah sebagai lembaga pendidikan formal memiliki peran yang sama dengan sekolah jenjang menengah lain yaitu SMA/SMK dalam rangka mengembangkan nilai-nilai dan potensi yang dimiliki siswa. Berdasarkan fenomena yang terjadi saat proses pembelajaran pada MA Swasta di kota Metro saat ini guru menghadapi banyak permasalahan yang berkaitan dengan pengelolaan pembelajaran di kelas, berdasarkan data awal yang didapatkan melalui wawancara dengan beberapa guru penulis mengidentifikasi masalah kedisiplinan siswa yang sering dialami oleh guru ketika mengajar yaitu siswa kurang perhatian, masuk kelas terlambat, siswa berbicara dengan temannya yang 
tidak terkait pelajaran, menggunakan telepon genggam secara diam-diam, tidak mengumpulkan tugas secara tepat waktu, serta mencontek.. Kondisi ini sesungguhnya tidak perlu terjadi atau dapat diminimalisasikan apabila guru sebagai pengelola pembelajaran di kelas dalam fungsi yang tepat

Guru MA di kota Metro yang hampir keseluruhan telah berpendidikan formal strata satu (S1) dalam hal ini diharapkan mampu meningkatkan, mampu menciptakan dan mengendalikan kelas agar tetap kondusif ketika proses belajar mengajar berlangsung serta mampu membangkitkan suasana belajar siswa yang kondusif sehingga pesan dari materi pelajaran dapat tersampaikan dengan baik. Berdasarkan argumen tersebut, Peran guru sebagai pemberi informasi harus bergeser menjadi manajer pembelajaran dengan sejumlah peran-peran tertentu, karena guru bukan satu-satunya sumber informasi melainkan hanya salah satu sumber informasi, kemampuan manajerial kelas merupakan kompetensi yang harus dimiliki oleh guru,mutlak diperlukan agar tujuan pembelajaran dapat tercapai secara optimal.

\section{METODOLOGI PENELITIAN}

Melihat makna yang tersirat dari judul dan permasalahan yang dikaji, Penelitian yang penulis gunakan dalam penelitian ini adalah penelitian kualitatif. penelitian yang dilakukan berdasarkan paradigma, strategi dan implementasi model secara kualitatif". (Basrowi dan Suwandi, 2008, h.20) Penelitian kualitatif adalah penelitian yang tidak memfokuskan pada keleluasaan tetapi lebih menekankan pada aspek "kedalaman" hasil penelitian. Instrumen penelitian tidak dirancang secara ketat, dengan pertanyaan-pertanyaan yang terstruktur. Analisis fakta lebih menekankan pada tehnik reflektive thinking, rasionalitas, relevansi, signifikansi dan kepekaan peneliti terhadap lingkungan penelitian. Penelitian kualitatif lebih bersifat holistik dan teoritik. (Basrowi dan Suwandi, 2008, h.10) Pendekatan yang peneliti gunakan adalah pendekatan fenomenologi. Menurut Moleong Pendekatan fenomenologi adalah pandangan berfikir yang menekankan pada fokus kepada pengalamanpengalaman subyektif manusia dan interpretasi dunia. (Lexy J. Moleong, 2006, h. 15)

Penelitian di lakukan di beberapa Madrasah Aliyah yang ada di kota Metro, untuk mendapatkan data obyektif tekhnik pengumpulan data yang dipergunakan dalam penelitian ini adalah Metode Pengamatan atau Observasi, Metode wawancara atau interview.

\section{HASIL DAN PEMBAHASAN}

\section{A. MANAJEMEN KELAS}

1. Pengertian

Kedudukan guru sebagai pendidik mempunyai peranan yang strategis dalam proses belajar mengajar, salah satunya yaitu sebagai pengelola kelas. Mengelola kelas dengan baik karena hal itu merupakan salah satu tugas guru yang tidak boleh ditinggalkan. Istilah lain dari kata pengelolaan adalah "manajemen". Manajemen adalah kata yang aslinya dari bahasa Iggris yaitu "management", 
yang berarti ketatalaksanaan, tata pimpinan, pengelolaan. Manajemen atau pengelolaan dalam pengertian umum adalah pengadministrasian, pengaturan atau penataan suatu kegiatan. (Syaiful Bahri djamarah dan Aswan Zain, 2002), h. 196). Sedangkan kelas didalam didaktik terkandung suatu pengertian, yaitu sekelompok siswa, yang pada waktu yang sama menerima pelajaran yang sama dari guru yang sama. (Suharsimi Arikunto, 1988, h. 17-18).

Manajemen kelas ialah "seperangkat kegiatan guru untuk mengembangkan hubungan interpersonal yang baik dan iklim sosio emosional yang positif". (Mulyadi, 2009, h.5). Pendapat lain mengatakan bahwa "Manajemen kelas merupakan ketrampilan guru menciptakan dan memelihara kondisi belajar yang optimal dan mengembalikannya manakala terjadi hal - hal yang dapat mengganggu suasana pembelajaran ".(Wina sanjaya,2005: 174). Menurut Suharsimi Arikunto " pengelolaan kelas adalah suatu usaha yang dilakukan oleh penanggung jawab kegiatan belajar mengajar atau yang membantu dengan maksud agar dicapai kondisi optimal sehingga dapat terlaksana kegiatan belajar seperti yang diharapkan." (Suharsimi Arikunto,1988:67-68). Berdasarkan kutipan tersebut dapat dipahami bahwa manajemen kelas adalah keterampilan guru untuk menciptakan dan memelihara kondisi belajar yang optimal dan mengembalikannya bila terjadi gangguan dalam proses belajar mengajar. Mengelola kelas dimaksudkan untuk menciptakan lingkungan belajar yang kondusif bagi anak didik sehingga tercapai tujuan pengajaran yang efektif dan efisien.

Pada dasarnya, kegiatan guru saat pengajaran berlangsung dapat dikelompokkan menjadi dua kegiatan pokok, yaitu pengelolaan pengajaran dan pengelolaan kelas. Pengelolaan pengajaran adalah kegiatan mengajar itu sendiri yang melibatkan secara langsung komponen materi pengajaran, metode mengajar, dan alat bantu mengajar dalam rangka mencapai tujuan pengajaran, sedangkan pengelolaan kelas adalah penciptaan kondisi yang mungkinkan pengelolan pengajaran dapat berlangsung secara optimal.

Suasana kelas harus dijaga supaya tetap kondusif. Untuk mencapai tujuan pengajaran di sekolah diperlukan guru yang mampu mengelola kelas dengan baik. Kelas yang dikelola dengan baik akan menunjang jalannya interaksi edukatif, sebaliknya kelas yang tidak dikelola dengan baik akan menghambat kegiatan pengajaran.. Allah SWT berfirman:

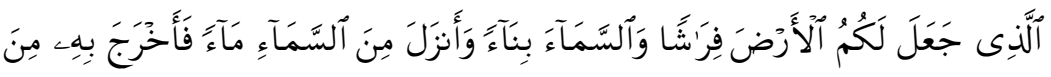

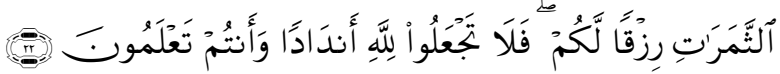

Artinya:

Dialah yang menjadikan bumi sebagai hamparan bagimu dan langit sebagai atap, dan Dia menurunkan air (hujan) dari langit, lalu Dia menghasilkan dengan hujan itu segala buahbuahan sebagai rezki untukmu; karena itu janganlah kamu Mengadakan sekutu-sekutu bagi Allah, padahal kamu mengetahui ( Q.S Al Baqarah :2:22). (Departemen Agama RI, 2000: 4)

Ayat tersebut di atas menjelaskan bahwa manajemen telah di contohkan oleh Allah SWT, contoh bagaimana Allah mengatur kelangsungan hidup Ciptaan-Nya. Artinya bagi guru, Kemampuan manajerial kelas merupakan salah satu syarat profesionalisme guru, oleh karena itu keberhasilan 
dalam manajemen kelas dapat dijadikan indikator penting atas tercapainya tujuan pengajaran. (Hasibuan dan Moedjiono,1995 :82) Kegiatan pengelolan kelas termasuk salah satu bagian dari motivasi ekstrinsik. Adapun motivasi ekstrinsik merupakan sekumpulan motif yang aktif dan berfungsi karena adanya perangsang dari luar. Guru harus pandai mempergunakan motivasi ekstrinsik dengan benar agar supaya proses interaksi edukatif di kelas dapat tercapai.

\section{Prinsip - Prinsip Manajemen kelas}

Dalam rangka memperkecil masalah gangguan dalam pengelolaan kelas, prinsip - prinsip pengelolaan kelas dapat dipergunakan. Maka penting bagi guru untuk mengetahui dan menguasai prinsip - prinsip pengelolaan kelas, diantaranya prinsip hangat, antusias, tantangan, bervariasi, keluwesan, penekanan pada hal-hal yang positif dan penanaman disiplin diri. (S. B. Djamarah \& Aswan Zain, $2002:$ 84)

\section{Tujuan Pengelolaan Kelas}

Pengelolaan kelas yang dilakukan oleh guru bukan tanpa tujuan, karena ada tujuan itulah guru selalu berusaha mengelola kelas walaupun terkadang kelelahan fisik maupun pikiran dirasakan. Seorang guru sadar tanpa mengelola kelas dengan baik, maka akan menghambat kegiatan belajar mengajarnya. Tujuan pengelolaan kelas pada hakikatnya telah terkandung dalam tujuan pendidikan. Secara umum tujuan pengelolaan kelas adalah penyediaan fasilitas bagi bermacam-macam kegiatan belajar siswa dalam lingkungan sosial, emosional, dan intelektual dalam kelas. (S. B. Djamarah \& Aswan Zain, 2002:200) Semua komponen keterampilan mengelola kelas mempunyai tujuan yang baik untuk anak didik maupun guru yaitu :

1. Untuk anak didik.

a) Mendorong anak didik mengembangkan tanggung jawab individu terhadap tingkah lakunya dan kebutuhan untuk mengontrol diri sendiri.

b) Membantu anak didik mengetahui tingkah laku yang sesuai dengan tata tertib kelas dan memahami bahwa teguran guru merupakan suatu peringatan dan bukan kemarahan.

c) Membangkitkan rasa tanggung jawab untuk melibatkan diri dalam tugas dan pada kegiatan yang diadakan.

Menurut Suharsimi Arikunto, tujuan pengelolaan kelas adalah agar setiap anak di kelas dapat bekerja dengan tertib sehingga segera tercapai tujuan pengajaran secara efektif dan efisien. Menurutnya sebagai indikator dari sebuah kelas yang tertib,sebagai berikut: (Suharsimi Arikunto, $1988: 69)$

a) Setiap anak terus bekerja, tidak macet, artinya tidak ada anak yang terhenti karena tidak tahu ada tugas yang harus dilakukan atau tidak dapat melakukan tugas yang diberikan kepadanya.

b) Setiap anak terus melakukan pekerjaan tanpa membuang waktu, artinya setiap anak akan bekerja secepatnya supaya lekas menyelesaikan tugas yang diberikan kepadanya. Apabila 
ada anak yang walaupun tahu dan dapat melaksanakan tugasnya, tetapi mengerjakannya kurang bergairah dan mengulur waktu bekerja, maka kelas tersebut dikatakan tidak tertib.

Jadi tujuan pengelolaan kelas adalah sebagai upaya mewujudkan situasi dan kondisi kelas, baik sebagai lingkungan belajar maupun sebagai kelompok belajar yang memungkinkan siswa untuk mengembangkan kemampuan semaksimal mungkin.

2. Untuk guru.

a) Mengembangkan pemahaman dalam penyajian pelajaran dengan petunjuk yang jelas dan kecepatan yang tepat.

b) Menyadari kebutuhan anak didik dalam pembelajaran di kelas dan memberikan motivasi dalam upaya meningkatkan hasil prestasi belajar.

c) Mempelajari bagaimana merespon secara efektif terhadap tingkah laku anak didik yang mengganggu.

d) Memiliki strategi remedial yang lebih komprehensif yang dapat digunakan dalam hubungannya dengan masalah tingkah laku anak didik yang muncul di dalam kelas.

Maka dapat disimpulkan bahwa hendaknya setiap guru mampu menguasai kelas dengan menggunakan berbagai macam pendekatan dengan tetap memperhatikan permasalahan yang ada, sehingga tercipta suasana pembelajaran yang kondusif, efektif dan efesien.

4. Komponen Keterampilan Pengelolaan Kelas

Bentuk keterampilan pengelolaan kelas pada umumnya dibagi menjadi dua bagian yaitu:

a) Keterampilan yang berhubungan dengan penciptaan dan pemeliharaan kondisi belajar yang optimal (bersifat preventif), Keterampilan ini berhubungan dengan kompetensi guru dalam mengambil inisiatif dan mengendalikan pelajaran. Aktivitas - aktivitas yang berkaitan dengan keterampilan ini adalah Sikap tanggap, Membagi perhatian, dan Pemusatan perhatian kelompok

b) Keterampilan yang Berhubungan dengan Pengembangan Kondisi Belajar yang Optimal. Keterampilan ini berkaitan dengan tanggapan guru terhadap gangguan anak didik yang berkelanjutan dengan maksud agar guru dapat mengadakan tindakan untuk mengembalikan kondisi belajar yang optimal. Hal ini dapat dilakukan dengan cara Modifikasi tingkah laku, Pendekatan pemecahan masalah kelompok, Menemukan dan memecahkan tingkah laku yang menimbulkan masalah. (S.B Djamarah \&Aswan Zain, 2002: 210)

\section{Pendekatan dalam Manajemen Kelas}

Pendekatan yang dilakukan oleh seorang guru dalam Manajemen Kelas akan sangat dipengaruhi oleh pandangan guru tersebut terhadap tingkah laku siswa, karakteristik watak dan sifat siswa, dan situasi kelas pada waktu seorang siswa melakukan penyimpangan. Beberapa pendekatan yang dapat dijadikan sebagai alternatif pertimbangan dalam upaya menciptakan disiplin kelas yang efektif, antara lain sebagai berikut:

a. Pendekatan Manajerial

Pendekatan ini dilihat dari sudut pandang manajemen yang berintikan konsepsi tentang 
kepemimpinan. Dalam pendekatan ini, dapat dibedakan menjadi:

1) Kontrol Otoriter; Dalam menegakkan disiplin kelas guru harus bersikap keras, jika perlu dengan hukuman-hukuman yang berat. Menurut konsep ini, disiplin kelas yang baik adalah apabila siswa duduk, diam, dan mendengarkan perkataan guru.

2) Kebebasan Liberal; menurut konsep ini, siswa harus diberi kebebasan sepenuhnya untuk melakukan kegiatan apa saja sesuai dengan tingkat perkembangannya. Dengan cara seperti ini, aktivitas dan kreativitas anak akan berkembang sesuai dengan kemampuannya.

3) Kebebasan Terbimbing; konsep ini merupakan perpaduan antara kontrol otoriter dan kebebasan liberal. Disini siswa diberi kebebasan untuk melakukan aktivitas, namun terbimbing atau terkontrol. (Sudirman N, dkk, 1992: 328)

b. Pendekatan Psikologis

Terdapat beberapa pendekatan yang didasarkan atas studi psikologis yang dapat dimanfaatkan oleh guru dalam membina disiplin kelas pada siswanya. Pendekatan yang dimaksud antara lain sebagai berikut :

1) Pendekatan Modifikasi Tingkah Laku (Behavior-Modification)

Pendekatan ini didasarkan pada psikologi behavioristik, yang mengemukakan pendapat bahwa Semua tingkah laku yang baik atau yang kurang baik merupakan hasil proses belajar. Ada sejumlah kecil proses psikologi penting yang dapat digunakan untuk menjelaskan terjadinya proses belajar yang dimaksud, yaitu diantaranya penguatan positif (positive reinforcement) seperti hadiah, ganjaran, pujian, pemberian kesempatan untuk melakukan aktivitas yang disenangi oleh siswa, dan penguatan negatif (negative reinforcement) seperti hukuman, penghapusan hak, dan ancaman.

2) Pendekatan Iklim Sosio-Emosional (Socio-Emotional Climate) Pendekatan ini berlandaskan psikologi klinis dan konseling yang mempradugakan: Proses Belajar Mengajar yang efektif mempersyaratkan keadaan sosio-emosional yang baik dalam arti terdapat hubungan antara pribadi guru dengan siswa dan antara siswa dengan siswa.Guru merupakan unsur terpenting bagi terbentuknya iklim sosio-emosional yang baik. Guru diperlukan bersikap tulus dihadapan siswa, menerima dan menghargai siswa sebagai manusia, dan mengerti siswa dari sudut pandang siswa sendiri. Dengan cara demikian, siswa akan dapat dikuasai tanpa menutup perkembangannya. Sebagai dasarnya, guru dituntut memiliki kemampuan untuk melakukan komunikasi yang efektif dengan siswa, sehingga guru dapat mendeskripsikan apa yang perlu dilakukannya sebagai alternatif penyelesaian.

3) Pendekatan Proses Kelompok (Group Process), Pendekatan ini berdasarkan pada psikologi klinis dan dinamika kelompok. Yang menjadi anggapan dasar dari pendekatan ini ialah: Pengalaman belajar sekolah berlangsung dalam konteks kelompok sosial, dan 
Tugas pokok guru yang utama dalam Manajemen Kelas ialah membina kelompok yang produktif dan efektif.

Pendekatan Elektif (Electic Approach), Pendekatan Elektik disebut juga dengan Pendekatan Pluralistik, yaitu Manajemen Kelas yang berusaha menggunakan berbagai macam pendekatan yang memiliki potensi untuk dapat menciptakan danmempertahankan suatu kondisi yang memungkinkan Proses Belajar Mengajar berjalan efektif dan efisien. Dimana guru dapat memilih dan menggabungkan secara bebas pendekatan tersebut, sesuai dengan kemampuan dan selama maksud dari penggunaannya untuk menciptakan Proses Belajar Mengajar berjalan secara efektif dan efisien. (Sudirman N, dkk, 1992: 328-332)

\section{B. Keterkaitan Antara Potensi Manajerial Kelas dan Situasi Pembelajaran}

Dalam situasi pendidikan, guru merupakan komponen yang memiliki peranan yang sangat penting dalam meningkatkan mutu pendidikan bagi tercapainya tujuan pendidikan Nasional. guru pada umumnya juga sebagai pondasi yang diharapkan dapat melahirkan peserta didik sebagai manusia yang tidak hanya dari satu aspek saja, tetapi meliputi aspek kognisi, afeksi dan psikomotorik.

Pada dasarnya guru yang memiliki kemampuan memanajemen kelas akan membuat suasana kelas kondusif untuk peserta didik mengikuti proses pembelajaran. Sehingga apabila atmosfer akademik pembelajaran sudah baik maka akan mempengaruhi siswa.

Dimensi pencegahan merupakan tindakan guru dalam mengatur lingkungan belajar, mengatur peralatan, dan lingkungan sosio-emosional. Lingkungan fisik tempat belajar mempunyai pengaruh penting terhadap hasil belajar. Lingkungan fisik yang menguntungkan dan memenuhi syarat, minimal mendukung meningkatnya intensitas proses kegiatan belajar dan mempunyai pengaruh positif terhadap pencapaian tujuan pengajaran.

\section{PENUTUP}

Guru merupakan komponen yang memiliki peranan yang sangat penting dalam meningkatkan mutu pendidikan bagi tercapainya tujuan pendidikan Nasional. guru pada umumnya juga sebagai pondasi yang diharapkan dapat melahirkan peserta didik sebagai manusia yang tidak hanya dari satu aspek saja, tetapi meliputi aspek kognisi, afeksi dan psikomotorik. Dalam pembelajaran guru merupakan manager dalam lingkungan belajar, kondusif dan stabilitas proses pembelajaran dipengaruhi oleh kemampuan guru dalam mengelola kelas. Sebagai manager pendidikan, guru kemudian dituntut untuk mampu menciptakan ide-ide kreatif dalam mengajar dan mengelola kelas tetap kondusif sehingga dapat membangkitkan motivasi siswa dalam mengikuti pembelajaran dengan baik.

\section{UCAPAN TERIMAKASIH}

Peneliti mengucapkan terima kasih kepada Universitas Muhammadiyah Metro, Madrasah Aliyah se-Kota Metro, LPPM STKIP Nurul Huda Sukaraja OKU Timur dan Tim Jurnal Al I'tibar Program Studi PAI STKIP Nurul Huda. 


\section{DAFTAR PUSTAKA}

Basrowi dan Suwandi,2018. Memahami Penelitian Kualitatif, Jakarta: Rineka Cipta.

Departemen Pendidikan Nasional RI,2008. UU RI No. 20 tahun 2003 tentang Sisdiknas ( Sistem Pendidikan Nasional ), Jakarta:Sinar Grafika.

Departemen Agama RI,2000. Al-Qur’an dan Terjemahan, Bandung : CV Penerbit Diponogoro.

Engkay Kerwati, 2010. Pengaruh Kemampuan Manajerial Kepala Sekolah dan Faktor yang Mempengaruhi Motivasi Kinerj Terhadap Kinerja Guru SLB di Kabupaten Subang, Jurnal Penelitian Pendidikan Vol. 11 No. 02.

Hasibuan \& Moedjiono, 1995. Proses Belajar Mengajar, Bandung : Remaja Rosda Karya.

Lefrancois, G.R, 2000. Psychology for Teaching (10th ed.). USA : Wadsworth Thomson Learning.

Lexy J. Moleong, 2006. Metodologi Penelitian Kualitatif, Bandung: Remaja Rosda Karya.

Miller, G., \& Hall, T. P, 2005. Classroom Management. Boston: National Center on Accessing the General Curriculum and U.S. Office of Special Education Programs.

Mulyadi, 2009. classroom Management: mewujudkan suasana kelas yang menyenangkan bagi siswa malang : UIN Malang.

Rahman dkk, 2005. Peran Strategis Kepala Sekolah dalam Meningkatkan Mutu Pendidikan, (Bandung: Alqaprint Jatinangor berkerjasama denganAsosiasi Kepala Sekolahlndonesia (AKSI).

Sudirman N, dkk, 1992. Ilmu Pendidikan (Bandung: Remaja Rosdakarya.

Suharsimi Arikunto,1996. Pengelolaan kelas dan siswa sebuah pendekatan evaluatif, Jakarta, Raja Grafindo Permai.

Syaiful Bahri djamarah dan Aswan Zain, 2002. Strategi Belajar Mengajar, Jakarta:Rineka Cipta.

Wina sanjaya, 2005. pembelajaran dalam implementasi kurikulum berbasis kemampuan, Jakarta : Kencana Prenada media Grup.

Sumber Data: Kantor Kementrian Agama Kota Metro tahun 2018.

Iswati ${ }^{1}$ dan Marlina ${ }^{2}$ 